\title{
Effect of Al on Expansion Behavior of Mg-Al Alloys During Solidification
}

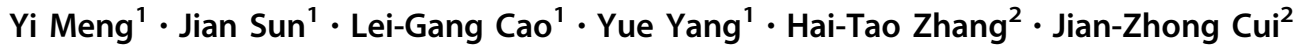

Received: 29 March 2018/Revised: 30 May 2018/Published online: 12 July 2018

(C) The Chinese Society for Metals and Springer-Verlag GmbH Germany, part of Springer Nature 2018

\begin{abstract}
The cooling curves and the change of contraction/expansion during solidification and cooling were tested by using a selfmade device which could achieve the one-dimensional contraction instead of three-dimensional contraction of the casting. Then, the effects of $\mathrm{Al}$ content $(0,1.1,3,5,10,12.9,15,17,19,22,24$ and $30 \mathrm{wt} \%)$ on the thermal contraction/expansion of the binary $\mathrm{Mg}-\mathrm{Al}$ as-cast alloys during solidification were obtained. The results showed that expanding instead of contraction was present in $\mathrm{Mg}-\mathrm{Al}$ alloys with the addition of $0-30 \mathrm{wt} \% \mathrm{Al}$ during solidification. The values of expansion significantly increased at first and then decreased with the increase in $\mathrm{Al}$ content. And the maximum expansion ratio of $0.44 \%$ (maximum expansion value: $0.841 \mathrm{~mm}$ ) was present in the $\mathrm{Mg}-15 \mathrm{wt} \% \mathrm{Al}$ alloy. Contraction instead of expansion occurred once the temperature drops to the temperature corresponding to the expansion value in total, indicating the occurrence of a continuous expansion during the solidification process in mushy zone for the $\mathrm{Mg}$ alloys with $\mathrm{Al}$ addition of 5-30 wt \%. The expansion value in total consisted of two parts: the expansions occurring in the liquid-phase zone and mushy zone. The expansion in liquid zone was present in every $\mathrm{Mg}-\mathrm{Al}$ alloy, and it contributed to the most proportion of the total expansion value when the $\mathrm{Al}$ content in $\mathrm{Mg}-\mathrm{Al}$ alloy was lower than $10 \mathrm{wt} \%$ or higher than $22 \mathrm{wt} \%$. However, the total expansion value was mainly determined by the solidification behavior in mushy zone when the $\mathrm{Al}$ content was among $10-22 \mathrm{wt} \%$ in $\mathrm{Mg}-\mathrm{Al}$ alloys.
\end{abstract}

Keywords Solidification $\cdot \mathrm{Mg}$ alloys $\cdot \mathrm{Al}$ content $\cdot$ Expansion

\section{Introduction}

Cast Mg alloys are of considerable interest because of their potential as high-strength, lightweight materials [1]. However, like many casting alloys, the contraction cavity and hot cracking (also referred to as hot tearing or solidification cracking), as two major defects in alloy castings, are prone to form during solidification of magnesium alloys because of the wide freezing range [1-3]. So both hot cracking and contraction cavity restrict potential

Available online at http://link.springer.com/journal/40195

Yi Meng

mengyi@ncut.edu.cn

1 School of Mechanical and Materials Engineering, North China University of Technology, Beijing 100144, China

2 Key Laboratory of Electromagnetic Processing of Materials, Ministry of Education, Northeastern University, Shenyang 110819, China application of magnesium alloys, especially for the increasing requirements with complex structure and/or thickness requirements $[4,5]$.

Currently, a number of $\mathrm{Mg}-\mathrm{Al}$ alloys components have been successfully used in automobiles for lightweight and ever-growing requirements of environment protection [6]. Since magnesium possesses high solubility in $\mathrm{Al}$ and therefore $\mathrm{Mg}-\mathrm{Al}$ alloy is sensitive to the solidification condition [7], it is necessary to study the effect of $\mathrm{Al}$ on the hot cracking and contraction cavity during solidification. Up to date, a number of studies have been carried out into the hot cracking behavior [8-16]. Wang et al. [4] studied the hot tearing behavior of commercial magnesium alloy AZ91 by using a crack-ring mold with a load cell and a thermocouple. Zhen et al. [14] studied the influence of mold temperature and $\mathrm{Al}$ content on hot tearing behavior of $\mathrm{Mg}-\mathrm{Al}$ binary alloys using a contraction force measuring method [17]. Cao and Kou [1] investigated the hot cracking of binary $\mathrm{Mg}-\mathrm{Al}$ alloy with the $\mathrm{Al}$ addition of $0.25-8 \mathrm{wt} \%$. There are also some other methods which could be used for 
these researches, including ring mold testing [4, 6], "cold finger" testing [9], backbone mold testing [10], constrained rod casting testing (CRC) [1, 10, 11], instrumented constrained rod casting testing [12-14] and in situ observation of hot tearing [15].

The hot cracking susceptibility of $\mathrm{Mg}-\mathrm{Al}$ alloy has been studied systematically by several methods, indicating that thermal contraction/inflation is the driving force to form cracking during solidification [15, 18]. Therefore, contraction behavior should be the key route to reveal the hot cracking susceptibility of the magnesium alloy. However, few studies are focused on studying the contraction behavior of $\mathrm{Mg}-\mathrm{Al}$ alloys.

In the present work, the effect of $\mathrm{Al}$ content on the contraction behaviors of $\mathrm{Mg}-\mathrm{Al}$ alloys was studied by using a self-made device which allows a more accurate measurement of contraction/expansion behavior. Although thermal expansion and cold contraction existed in most of metal alloys, significant expansion was observed for the first time during the solidification of $\mathrm{Mg}-\mathrm{Al}$ alloys, which presented strong relationship with the content of $\mathrm{Al}$ element. Therefore, the purpose of the present study is to investigate the effect of $\mathrm{Al}$ content on expansion behavior instead of contraction behavior for $\mathrm{Mg}-\mathrm{Al}$ alloys during solidification, especially for the expansion behaviors in liquid zone and mushy zone.

\section{Experimental}

$\mathrm{Mg}-x \mathrm{Al}$ alloys with different $\mathrm{Al}$ contents $(x=0,1.1,3,5$, $10,12.9,15,17,19,22,24$ and $30 \mathrm{wt} \%$ ) were prepared in an electrical resistance furnace using a mild steel crucible by melting mixture of pure magnesium and aluminum. After stirring for $2 \mathrm{~min}$ and holding for $5 \mathrm{~min}$ at $700{ }^{\circ} \mathrm{C}$ in the electrical resistance furnace, the melt was heated at $720{ }^{\circ} \mathrm{C}$ and then poured into a preheated mold $\left(300{ }^{\circ} \mathrm{C}\right)$ which was called displacement tested module as shown in Fig. 1. Some $\mathrm{CO}_{2}$ gas was bled into the mold to avoid the oxidation of casting before the molten liquid being poured into the mold.

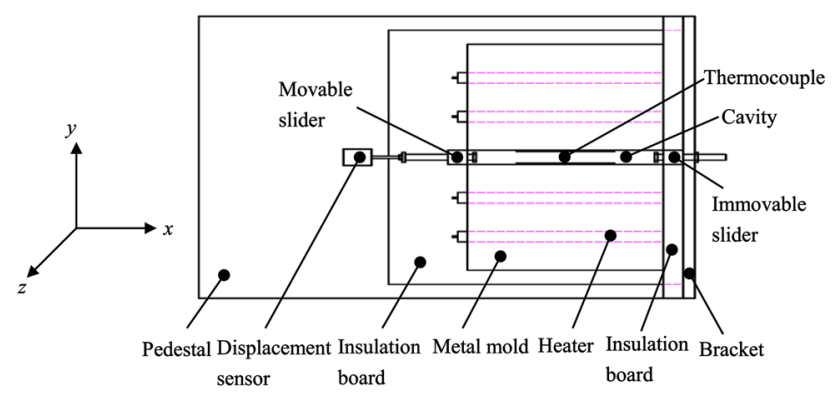

Fig. 1 Schematic diagram of displacement tested module
Figure 1 shows a schematic illustration of the displacement tested module used in this study. The solidification of the liquid was performed in the well-designed cavity $(20 \mathrm{~mm} \times 20 \mathrm{~mm} \times 190 \mathrm{~mm}$ in size $)$, which was assembled by three parts: (1) two pieces of insulation boards in the position along the $z$-axis direction; (2) two metal molds, which were placed on both sides of the cavity along the $y$-axis direction for heating the mold; and (3) two steel sliders, with the movable one being connected with the displacement sensor and the immovable one being fixed on the insulation board along the direction of the $x$-axis. The low thermal conductivity of two insulation boards and the heating design of metal molds resulted in the lowest temperature at both ends of the cavity during experimental process. As a result, the main heat flow direction of the melt was from the center of the cavity to both ends of the cavity along the direction of $x$-axis. Therefore, the shrinkage of the casting should be almost carried out from both ends of casting to the center along the $x$-axis, resulting in the approximate one-dimensional contraction instead of the three-dimensional contraction. During the solidification and cooling process of the liquid, both steel sliders were connected with the alloy. Therefore, since the immovable steel slider was fixed on the pedestal, the data collected by the displacement sensor connected with the movable steel slider could indicate the whole variation of casting in size with temperature dropping.

In order to measure the tiny displacement value of casting during solidification and subsequent cooling process, the linear variable differential transformer (type: 250 DC-SE) with high sensitivity and high accuracy was used. Meanwhile, K-thermocouple wire was placed at the center of cavity shown in Fig. 1 to weaken its resistance to the contraction/expansion of casting during solidification. The temperature and the signal from the 250 DC-SE were then collected by HIOKI data collector with the collecting cycle being $10 \mathrm{~ms}$, which gives the way to study the dependency of temperature and displacement variation on time. The microstructures of the $\mathrm{Mg}-\mathrm{Al}$ ingots were investigated by the scanning electron microscopy (SEM, Carl Zesis Sigma300), equipped with a Bruker energy-dispersive spectrometer (EDS) for composition analysis. Rigaku Ultima IV type X-ray diffraction (XRD) was used to identify phases in $\mathrm{Mg}-\mathrm{Al}$ alloys with different $\mathrm{Al}$ addition.

\section{Results}

Figure 2 shows the variation of temperature $(T)$ and displacement $(l)$ as a function of time $(t)$ for the studied magnesium alloys with different Al contents, wherein the decrease and increase in displacement correspond to expansion and contraction of the alloy, respectively. Pure 

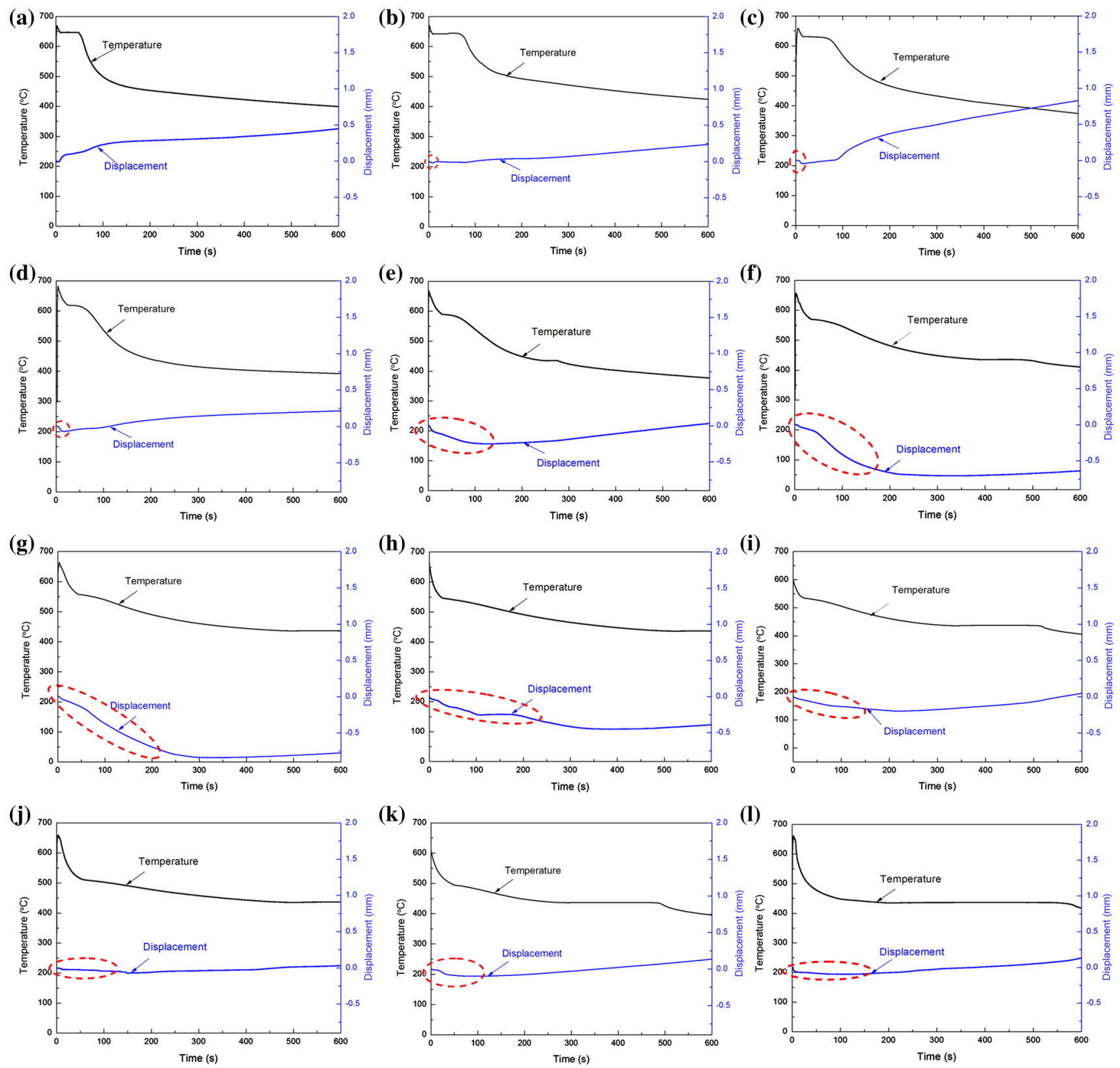

Fig. 2 Curves of time-temperature $(t-T)$, time-displacement $(t-l)$ of $\mathrm{Mg}-\mathrm{Al}$ alloys with different $\mathrm{Al}$ contents: a 0 wt $\%$; b 1 wt $\%$; c 3 wt $\%$; d 5 wt $\%$; e 10 wt $\%$; f 12.9 wt $\%$; g 15 wt $\%$; h 17 wt $\%$; i 19 wt $\%$; j 22 wt $\%$; k 24 wt $\%$; 30 wt $\%$

magnesium almost presents a simple contraction phenomenon, while the expansion behavior turns up prior to the onset of contraction for the $\mathrm{Mg}-\mathrm{Al}$ alloys with the addition of $\mathrm{Al}$ element. The expansion value firstly increases and then decreases with the increase in $\mathrm{Al}$ content.

The total expansion values $(L)$ of studied alloys during the entire solidification process are then summarized in Fig. 3a and Table 1, indicating a slight increase in $L$ from $0.011 \mathrm{~mm}$ (pure magnesium) to $0.069 \mathrm{~mm}(\mathrm{Mg}-5 \mathrm{wt} \% \mathrm{Al}$ alloy) and then a rapid increase to the maximum value of
$0.841 \mathrm{~mm}$ (Mg-15 wt\% Al alloy), following by a rapid decrease to $0.084 \mathrm{~mm}$ (Mg-30 wt\% Al alloy). In comparison with the original length of ingot $(190 \mathrm{~mm})$, the maximum expansion ratio of the $\mathrm{Mg}-\mathrm{Al}$ alloy can be indicated as $0.44 \%(0.841 \mathrm{~mm} / 190 \mathrm{~mm} \times 100 \%)$.

Figure $3 \mathrm{~b}$ presents the temperature corresponding to the max expansion $\left(T_{\mathrm{L}}\right)$ as a function of the $\mathrm{Al}$ content, as well as the liquidus and solidus lines predicted by the equilibrium $\mathrm{Mg}-\mathrm{Al}$ phase diagram. Contraction instead of expansion occurs once the temperature drops to $T_{\mathrm{L}}$. It can be concluded from Fig. $3 \mathrm{a}$ and $\mathrm{b}$ that the variation of $T_{\mathrm{L}}$ 
(a)

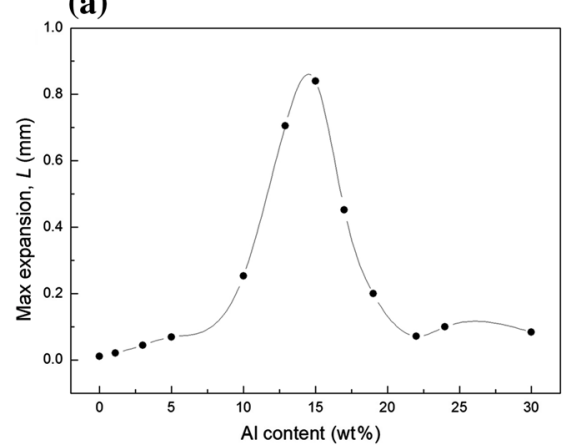

(b)

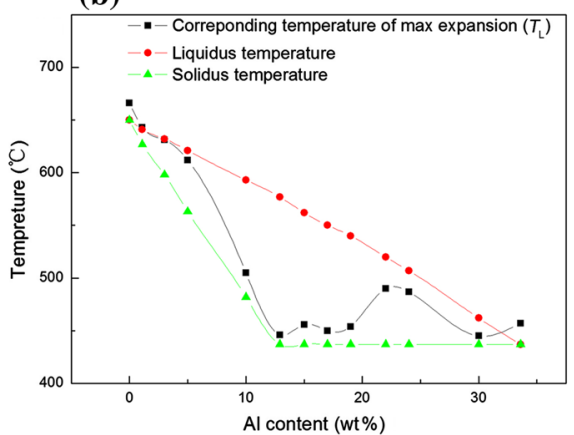

(c)

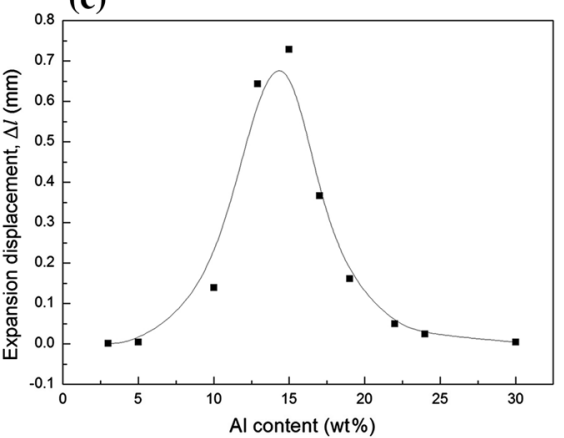

Fig. 3 a Max expansion, b liquidus temperatures, solidus temperatures and corresponding temperatures of max expansion, c expansion displacement measured between liquidus temperature and corresponding temperature of max expansion of $\mathrm{Mg}-\mathrm{Al}$ alloys with different $\mathrm{Al}$ contents during solidification

Table 1 Highest temperature in cavity, max expansion values $(L)$, the corresponding expansion displacements between liquidus temperatures and $T_{\mathrm{L}}(\Delta l)$, and their expansion displacements in liquid-phase zone $(L-\Delta l)$ for $\mathrm{Mg}-\mathrm{Al}$ alloys with different $\mathrm{Al}$ contents during solidification

\begin{tabular}{lllllllllll}
\hline Al content $(\mathrm{wt} \%)$ & 3 & 5 & 10 & 12.9 & 15 & 17 & 19 & 22 & 24 \\
\hline Highest temperature $\left({ }^{\circ} \mathrm{C}\right)$ & 658.6 & 682.5 & 668 & 657.1 & 663.9 & 650.9 & 662 & 658 & 610.4 & 661.3 \\
$L(\mathrm{~mm})$ & 0.045 & 0.069 & 0.254 & 0.706 & 0.841 & 0.452 & 0.200 & 0.072 & 0.100 & 0.084 \\
$\Delta l(\mathrm{~mm})$ & 0.001 & 0.004 & 0.140 & 0.644 & 0.730 & 0.366 & 0.161 & 0.050 & 0.024 & 0.005 \\
$L-\Delta l(\mathrm{~mm})$ & 0.044 & 0.065 & 0.114 & 0.062 & 0.111 & 0.086 & 0.039 & 0.022 & 0.076 & 0.079 \\
\hline
\end{tabular}

with the Al content presents a similar profile with the solidus line, indicating the occurrence of a continuous expansion during the solidification process in mushy zone for $\mathrm{Mg}$ alloys with 5-30 wt\% $\mathrm{Al}$ addition. It can be noted that the expansion value in total (Fig. 3a) should consist of two parts: the expansions occurring in the liquid-phase zone and mushy zone.

Figure $3 \mathrm{c}$ shows the corresponding expansion displacements $(\Delta l)$ between liquidus temperature and $T_{\mathrm{L}}$ for the $\mathrm{Mg}-\mathrm{Al}$ alloys with 3-30 wt\% Al addition, following a similar trend with the total expansion $L$ in Fig. 3a, indicating the observed variation of expansion originated from the solidification process in mushy zone. The difference of expansion value for each $\mathrm{Mg}-\mathrm{Al}$ alloys between Fig. 3a and c, which is $L-\Delta l$ with a random distribution (Table 1) representing the expansion occurring in the liquid-phase zone, irrespective of the alloy composition, presents a low contribution of expansion to the total expansion value $(L)$ when the $\mathrm{Al}$ content in $\mathrm{Mg}$ alloys is higher than $10 \mathrm{wt} \%$ and lower than $22 \mathrm{wt} \%$. The detailed data are given in Table 1 . So it means that the expansion mainly occurs at the region between liquidus temperature and $T_{\mathrm{L}}$, but not at the liquid-phase region for the $\mathrm{Mg}-\mathrm{Al}$ alloys with $\mathrm{Al}$ addition among 10-22 wt\%. However, the expansion is mainly carried out at the liquid-phase region due to the small difference between $L$ and $L-\Delta l$ in value $(<0.079 \mathrm{~mm})$ when the $\mathrm{Al}$ content in the $\mathrm{Mg}-\mathrm{Al}$ alloys is lower than $10 \mathrm{wt} \%$ or higher than $22 \mathrm{wt} \%$. The expansion present at the liquid-phase region might be caused by the discharging of gas in the liquid $\mathrm{Mg}$ alloy with a lower solubility.

Figure 4 shows the XRD patterns of the Mg alloys with different $\mathrm{Al}$ addition. It can be seen that $\alpha-\mathrm{Mg}$ phase is observed in the XRD patterns in all alloys. For the alloys with the $\mathrm{Al}$ content higher than $10 \mathrm{wt} \%$, a low fraction of

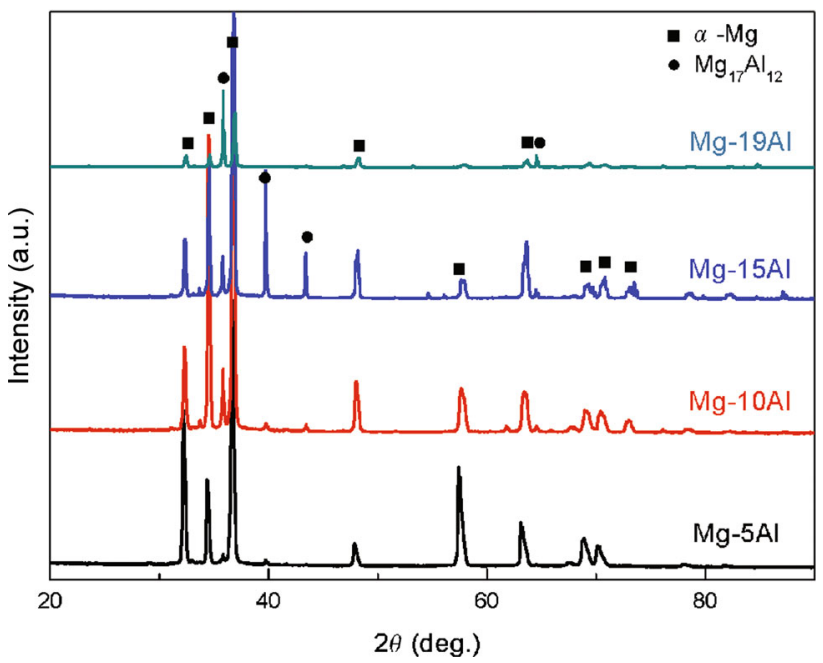

Fig. $4 \mathrm{XRD}$ patterns of as-cast $\mathrm{Mg}-\mathrm{Al}$ alloys with different $\mathrm{Al}$ addition 
the $\mathrm{Mg}_{17} \mathrm{Al}_{12}$ phase is also identified. Although only $\alpha-\mathrm{Mg}$ phase could be present in $\mathrm{Mg}-\mathrm{Al}$ alloys with the $\mathrm{Al}$ addition of $<12.9 \mathrm{wt} \%$ after solidification process according to the equilibrium phase diagram, non-equilibrium solidification condition will cause the formation of the primary $\gamma-\mathrm{Mg}_{17} \mathrm{Al}_{12}$ phase, and at the last stage of solidification, the $\alpha-\mathrm{Mg}+\gamma-\mathrm{Mg}_{17} \mathrm{Al}_{12}$ binary eutectic is formed at $473{ }^{\circ} \mathrm{C}$ [19]. Therefore, it can be thought that the $\mathrm{Mg}_{17} \mathrm{Al}_{12}$ phases shown in Fig. 4 should be consisted of primary $\gamma-\mathrm{Mg}_{17} \mathrm{Al}_{12}$ phase and $\gamma-\mathrm{Mg}_{17} \mathrm{Al}_{12}$ in $\alpha+\gamma$ binary eutectic.

Correspondingly, the microstructures of $\mathrm{Mg}$ alloys with $\mathrm{Al}$ addition of 5, 10, 15 and $19 \mathrm{wt} \%$ were also studied by SEM as shown in Fig. 5. $\alpha-\mathrm{Mg}$, primary $\gamma-\mathrm{Mg}_{17} \mathrm{Al}_{12}$ phases in grain boundaries and $\alpha-\mathrm{Mg}+\gamma-\mathrm{Mg}_{17} \mathrm{Al}_{12}$ binary eutectic phases $[19,20]$ can be found in Fig. 5. The number of $\gamma-\mathrm{Mg}_{17} \mathrm{Al}_{12}$ phases increases with the increase in $\mathrm{Al}$ content. In $\mathrm{Mg}-5 \mathrm{wt} \% \mathrm{Al}$ alloy, a small proportion of $\gamma$ $\mathrm{Mg}_{17} \mathrm{Al}_{12}$ phases (1.47\%) and most of the $\gamma-\mathrm{Mg}_{17} \mathrm{Al}_{12}$ phases should be annotated as primary $\gamma-\mathrm{Mg}_{17} \mathrm{Al}_{12}$ phases in grain boundaries with the area fraction of $1.17 \%$ (Fig. 5a). With the increase in $\mathrm{Al}$ content, the fraction of the $\alpha$-Mg phase in the solidified casting decreases and the interdendritic region solidifies into a eutectic structure between $\alpha-\mathrm{Mg}$ and $\gamma-\mathrm{Mg}_{17} \mathrm{Al}_{12}$. The area fraction of $\gamma$ $\mathrm{Mg}_{17} \mathrm{Al}_{12}$ phases increases dramatically to $6.9 \%$ in $\mathrm{Mg}-$ $10 \mathrm{wt} \% \mathrm{Al}$ alloy (Fig. 5b), 25.21\% in Mg-15 wt\% $\mathrm{Al}$ alloy
(Fig. 5c) and $34.46 \%$ in $\mathrm{Mg}-19 \mathrm{wt} \% \mathrm{Al}$ alloy (Fig. 5d). Additionally, the number of primary $\gamma-\mathrm{Mg}_{17} \mathrm{Al}_{12}$ phases increases slightly to $1.36,1.60$ and $2.54 \%$ in $\mathrm{Mg}-10,15$ and $19 \mathrm{wt} \% \mathrm{Al}$ alloy, respectively. There is no doubt that neither primary $\gamma-\mathrm{Mg}_{17} \mathrm{Al}_{12}$ phase nor eutectic phase could be present in pure $\mathrm{Mg}$ ingot. Therefore, it can be concluded that the number of $\alpha-\mathrm{Mg}+\gamma-\mathrm{Mg}_{17} \mathrm{Al}_{12}$ eutectic phases should increase significantly once $\mathrm{Al}$ content is higher than $5 \mathrm{wt} \%$ in $\mathrm{Mg}-\mathrm{Al}$ alloys.

\section{Discussion}

With the increase in volume fraction of the remaining eutectic liquid in the interdendritic region, it could be reasonable that the duration of expansion behaviors for the $\mathrm{Mg}-\mathrm{Al}$ alloys with the $\mathrm{Al}$ content in excess of $5 \mathrm{wt} \%$ is significantly longer than that of the $\mathrm{Mg}-\mathrm{Al}$ alloys with low $\mathrm{Al}$ content in Fig. 2. Even if the total expansion values are small for the $\mathrm{Mg}-\mathrm{Al}$ alloys with $\mathrm{Al}$ addition of $\leq 5$ or $>22 \mathrm{wt} \%$, the duration of expansion phenomenon for the $\mathrm{Mg}-\mathrm{Al}$ alloys with $\mathrm{Al}$ addition of $>22 \mathrm{wt} \%$ is obviously longer than that of expansion behaviors for the $\mathrm{Mg}-\mathrm{Al}$ alloys with $\mathrm{Al}$ addition of $\leq 5 \mathrm{wt} \%$, based on Figs. 2, 3a and Table 1 . In addition, for these alloys (Al content $\leq 5$ and $>22 \mathrm{wt} \%$ ), the major contribution of the total
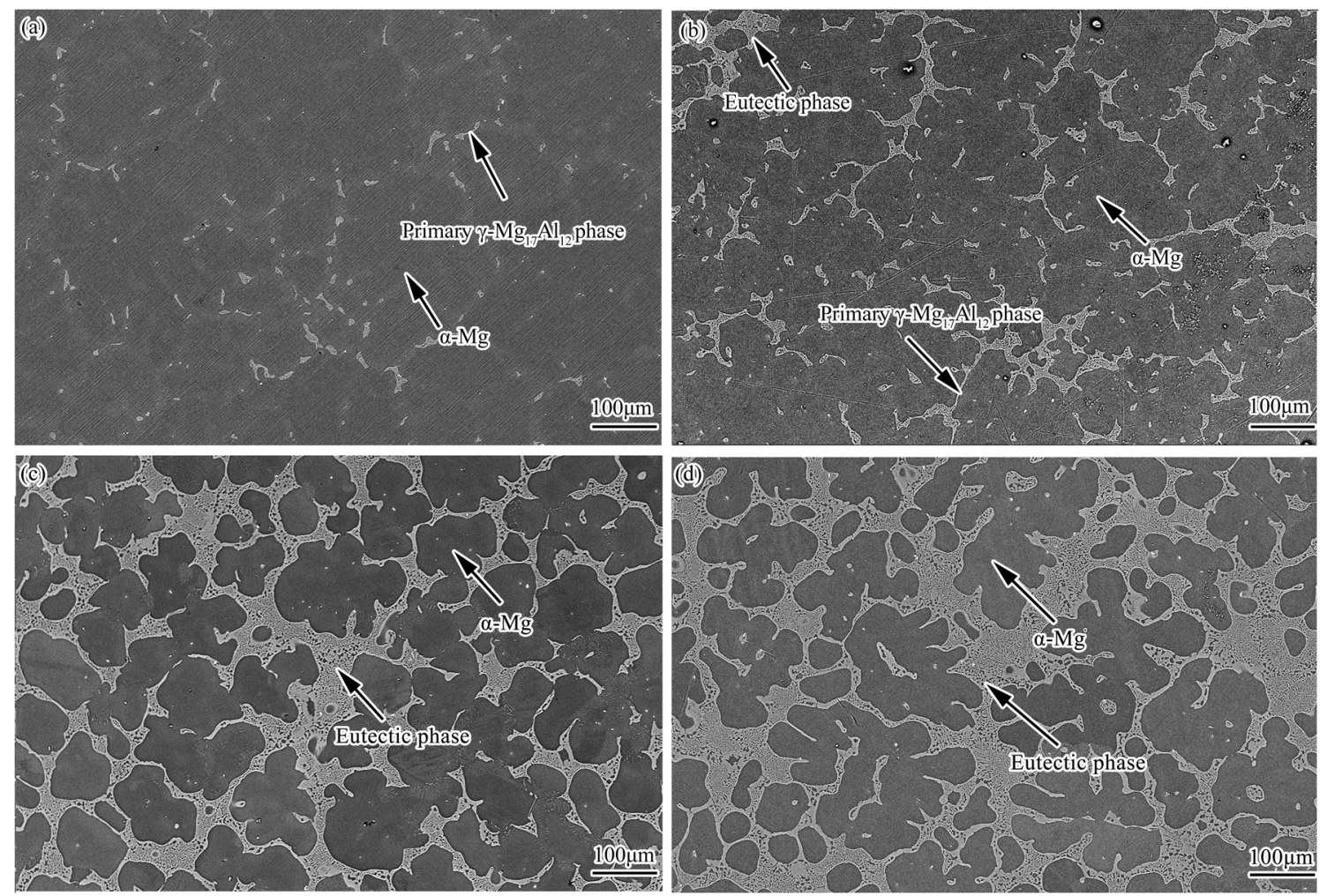

Fig. 5 SEM microstructures of $\mathrm{Mg}-\mathrm{Al}$ alloys with different $\mathrm{Al}$ contents: a 5 wt \%; b 10 wt \%; c 15 wt\%; d 19 wt $\%$ 
expansion $(L)$ is from the cooling of the liquid, $L-\Delta l$, in comparison with $\Delta l$ (Fig. 3c), which is because of the reaction of the gas evolution.

As shown in Fig. 2, the expansion behavior of the $\mathrm{Mg}-$ Al alloy during solidification could be divided into two individual stages, namely the expansion and subsequent contraction. According to the study by Eskin et al. [10] and Stangeland et al. [21], the expansion behavior of the aluminum alloy prior to the onset of contraction in the horizontal direction could be affected by the amount of gas in the melt, the melting conditions and the alloying system; therefore, they also concluded that the coherent structure of the ingot would prevent further expansion caused by gas evolution during solidification. As a result, the discharging of gas should give rise to a slight expansion in liquid zone (the data of $L-\Delta l$ ), but the expansion caused by the gas evolution can be negligible in mushy zone due to formation of coherent structure. This argument could be supported by the observation of the remarkable expansion of the $\mathrm{Mg}-\mathrm{Al}$ alloys, highlighted by red circles in Fig. 2, and the random distribution of $L-\Delta l$ which is independent to the change of $\mathrm{Al}$ content in Table 1. In the course of the data collection, the highest temperatures of the liquid measured in the mold before solidification were almost the same (Table 1), except for the $\mathrm{Mg}-24 \mathrm{wt} \% \mathrm{Al}$ alloy. In addition, the melts were prepared in the electric furnace with the same operating procedure and the mold was preheated to $300{ }^{\circ} \mathrm{C}$ for all of the studied alloys. Therefore, the solidification condition of the $\mathrm{Mg}-\mathrm{Al}$ alloys with the $\mathrm{Al}$ addition of 0-30 wt\% in this study could be considered as the same. The alloying system becomes the only factor giving rise to the observed expansion of the $\mathrm{Mg}-\mathrm{Al}$ alloys in mushy zone, and the gas evolution should be the main reason to cause the expansion in liquid-phase zone.

It can be concluded from Fig. 3 that significant expansion of $\mathrm{Mg}-\mathrm{Al}$ alloys is present before contraction when the $\mathrm{Al}$ content is in excess of $5 \mathrm{wt} \%$. Besides, the maximum expansion was mainly observed within the temperature range of the liquidus and solidus lines for the $\mathrm{Mg}-\mathrm{Al}$ alloys with the Al addition of 10-22 wt\%, indicating a strong correlation with the liquid-solid transition process (so-called solidification process). Although the expansion occurred in liquid zone $(L-\Delta l)$ will also affect the total expansion value to some extent, its influence on expansion $(L-\Delta l)$ is usually small for the $\mathrm{Mg}-\mathrm{Al}$ alloys with the $\mathrm{Al}$ addition of 10-22 wt\% (Table 1). Additionally, obvious expansion with great change is also present in $\mathrm{Mg}$ alloys with $\mathrm{Al}$ addition of $>5 \mathrm{wt} \%$.

It is necessary to classify the solidification mechanism in detail in order to understand the expanding nature of the $\mathrm{Mg}-\mathrm{Al}$ alloys. Based on the $\mathrm{Mg}-\mathrm{Al}$ equilibrium phase diagram and Fig. 5, Mg-matrix $(\alpha-\mathrm{Mg})$, primary $\gamma-\mathrm{Mg}_{17-}$ $\mathrm{Al}_{12}$ phases and most of $\alpha-\mathrm{Mg}+\gamma-\mathrm{Mg}_{17} \mathrm{Al}_{12}$ eutectic phases are formed in mushy zone. Meanwhile, the max expansion values of $\mathrm{Mg}$ alloys with $\mathrm{Al}$ addition of 5-30 wt\% are present in mushy zone (Fig. 3). Therefore, the predicted solidification path from the $\mathrm{Mg}-\mathrm{Al}$ melt would be for single-phase $\alpha$-Mg (dendritic morphology in the present paper) to form first, which will increase the $\mathrm{Al}$ concentration of the remaining liquid until this equals the eutectic composition, wherein the residual liquid solidified to single-phase $\gamma-\mathrm{Mg}_{17} \mathrm{Al}_{12}$ in grain boundaries for the alloys with low $\mathrm{Al}$ content $(\leq 5 \mathrm{wt} \%)$ and the $\alpha-\mathrm{Mg}+\gamma-$ $\mathrm{Mg}_{17} \mathrm{Al}_{12}$ eutectic structure for the alloys with high $\mathrm{Al}$ content $(>5 \mathrm{wt} \%)$. Additionally, the increase in primary $\gamma$ $\mathrm{Mg}_{17} \mathrm{Al}_{12}$ phases in number should be limited because the eutectic reaction will be present soon. In this process, the remaining interdendritic liquid will act as a heat sink for the latent heat released upon solidification, namely that the formation of the solid-phase $\alpha-\mathrm{Mg}$ in the first step will be always accompanied by the continued evolution of latent heat during growth, resulting in continuous warming (expansion) of the remaining liquid in the interdendritic region. It should be noted that the thermal expansion of the liquid would be more remarkable than that of the solid phase during "heating process" caused by the release of latent heat (recalescence phenomenon) [22]. Here, we attribute the observed variation of the total expansion to the interplay of the expansion caused by the interdendritic remaining liquid and the total amount of latent heat released by $\alpha-\mathrm{Mg}$ and primary $\gamma-\mathrm{Mg}_{17} \mathrm{Al}_{12}$ phase.

As a result, the change of expansion of these alloys can be divided into three parts: (1) Al content $<10 \mathrm{wt} \%$. For the $\mathrm{Mg}-\mathrm{Al}$ alloys with low $\mathrm{Al}$ concentration, the melt will solidify into a matrix of $\alpha-\mathrm{Mg}$ and the $\gamma-\mathrm{Mg}_{17} \mathrm{Al}_{12}$ phases with a proportion of $1.17 \%$ in Fig. 5a. Although high quantity of latent heat would be expected during the solidification process, the measured expansion of the alloys was limited, with the values being 0.045 and $0.069 \mathrm{~mm}$ for $\mathrm{Mg}-3 \mathrm{wt} \% \mathrm{Al}$ and $\mathrm{Mg}-5 \mathrm{wt} \% \mathrm{Al}$ alloys, respectively. This is quite reasonable since such a low fraction of the remaining liquid $(\leq 0.3 \%)$ will not give rise to significant expansion of the alloy during solidification. So the value of total expansion $(L)$ slightly increases with the increase in Al content. But the amount of expansion value caused in mushy zone $(\Delta l)$ is small, and as a result, the maximum expansion value is mostly determined by the gas discharging in liquid zone; (2) Al content is among $10-15 \mathrm{wt} \%$. The increase in the Al content will decrease the fraction of the $\alpha-\mathrm{Mg}$ phase and, in turn, increase the fraction of the eutectic gradually. The loss of the $\alpha-\mathrm{Mg}$ solid, to a certain degree, will not weak the total amount of the released latent heat too much, while the increasing fraction of the eutectic will give rise to enhanced ability of expansion. Therefore, the measured expansion in total increases rapidly to a maximum value, being $0.841 \mathrm{~mm}$ for 
$\mathrm{Mg}-15 \mathrm{wt} \% \mathrm{Al}$ alloy. That is to say, the expansion phenomenon could become remarkable only if the fraction of the remaining liquid exceeds a certain value $(>0.3 \%$ in $\mathrm{Mg}-5 \mathrm{wt} \% \mathrm{Al}$ ); (3) $\mathrm{Al}$ content is among $15-30 \mathrm{wt} \%$. The expansion of the alloy will not keep increasing with increasing $\mathrm{Al}$ content, since increasing the remaining liquid, acting as a heat sink, will not be re-heated effectively by the decreasing latent heat as the fraction of the $\alpha-\mathrm{Mg}$ phase is decreased. Therefore, the measured expansion in total decreased rapidly to $0.072 \mathrm{~mm}$ for $\mathrm{Mg}-22 \mathrm{wt} \% \mathrm{Al}$ alloy. Besides, the expansion value in mushy zone has decreased so largely that little expansion in mushy zone $(<0.024 \mathrm{~mm})$ is present when the $\mathrm{Al}$ content in $\mathrm{Mg}-\mathrm{Al}$ alloy is in excess of $22 \mathrm{wt} \%$. The limited latent heat released by decreased primary $\alpha-\mathrm{Mg}$ phase will definitely not give rise to serious expansion toward to a large fraction of the eutectic melt, although the alloy still presents a weak expansion behavior in total, being 0.100 and $0.084 \mathrm{~mm}$ for $\mathrm{Mg}-24 \mathrm{wt} \% \mathrm{Al}$ and $\mathrm{Mg}-30 \mathrm{wt} \% \mathrm{Al}$ alloys.

\section{Conclusions}

1. The obvious expansion with significant change in $\mathrm{Mg}-$ $\mathrm{Al}$ alloys is present before contraction during solidification, and the maximum expansion ratio of $0.44 \%$ $(0.841 \mathrm{~mm})$ is present in the $\mathrm{Mg}-15 \mathrm{wt} \% \mathrm{Al}$ alloy.

2. The max expansion values are consisted of the sum of expansion values in both liquid-phase zone and mushy zone for $\mathrm{Mg}-\mathrm{Al}$ alloys with $\mathrm{Al}$ addition of 5-30 wt\%.

3. The expansion in liquid zone is present in every $\mathrm{Mg}_{-}$ Al alloy, but the total expansion value is mainly determined by the solidification behavior in mushy zone when the $\mathrm{Al}$ content is among 10-22 wt\% in $\mathrm{Mg}-$ $\mathrm{Al}$ alloys. Conversely, the total expansion value is mainly attributed to expansion in liquid-phase zone in the $\mathrm{Mg}-\mathrm{Al}$ alloys with the $\mathrm{Al}$ addition of $<10$ or $>22 \mathrm{wt} \%$.

Acknowledgements This work was financially supported by the Beijing Natural Science Foundation (No. 2164060), the Training
Program Foundation for the Talents by Beijing (No. 2015000020124G023) and Yuqing Talent Development Program of North China University of Technology (No. 18XN012-079).

\section{References}

[1] G. Cao, S. Kou, Mater. Sci. Eng. A 417, 230 (2006)

[2] M. Paliwal, I.H. Jung, Acta Mater. 61, 4848 (2013)

[3] W.C. Zheng, S.S. Li, B. Tang, D.B. Zeng, Chin. Foundary 3, 270 (2006)

[4] Y.S. Wang, B.D. Sun, Q.D. Wang, Mater. Lett. 53, 35 (2002)

[5] H. Huang, P.H. Fu, Y.X. Wang, L.M. Peng, H.Y. Jiang, Trans. Nonferr. Met. Soc. Chin. 24, 922 (2014)

[6] H.W. Pan, Z.Q. Han, B.C. Liu, J. Mater. Sci. Technol. 32, 68 (2016)

[7] S. Zhao, Q. Peng, H. Li, B. Liu, J. Alloys Compd. 584, 56 (2014)

[8] I.I. Novikov, O.E. Grushko, Mater. Sci. Technol. 11, 926 (1995)

[9] J.M. Drezet, M. Rappaz, Modeling of Casting, Welding, and Advanced Solidification Process VIII (Springer, San Antonio, 1998), pp. 883-890

[10] D.G. Eskin, L.Katgerman Suyitno, Prog. Mater Sci. 49, 629 (2004)

[11] P. Gunde, A. Schiffl, P.J. Uggowitzer, Mater. Sci. Eng. A 527, 7074 (2010)

[12] G. Cao, S. Kou, Metall. Mater. Trans. A 37, 3647 (2006)

[13] G. Cao, I. Haygood, S. Kou, Metall. Mater. Trans. A 41, 2139 (2010)

[14] Z. Zhen, N. Hort, Y. Huang, N. Petri, O. Utke, K.U. Kainer, Mater. Sci. Forum 618-619, 533 (2009)

[15] K. Hu, A.B. Phillion, D.M. Maijer, S.L. Cockcroft, Scr. Mater. 60, 427 (2009)

[16] J.F. Song, F.S. Pan, B. Jiang, A. Atrens, M.X. Zhang, Y. Lu, J. Magnes, Alloys 4, 151 (2016)

[17] Z.S. Zhen, N. Hort, Y.D. Huang, O. Utke, N. Petri, Cast Met. 22, 331 (2013)

[18] G.P. Cao, S. Kou, Y.A. Chang, Magnesium Technology (Springer, Hoboken, 2014), pp. 205-209

[19] N. Katarzyna, B. Malik, Precipitates of $\gamma-M g_{17} A l_{12}$ Phase in AZ91 Alloy, Magnesium Alloys-Design, Processing and Properties (Springer, Croatia, 2011), pp. 95-112

[20] M. Esmaily, M. Shahabi-Navid, N. Mortazavi, J.E. Svensson, M. Halvarsson, M. Wessén, A.E.W. Jarfors, L.G. Johansson, Mater. Charact. 95, 50 (2014)

[21] A. Stangeland, A. Mo, N. Øyvind, D.G. Eskin, M. M'Hamdi, Metall. Mater. Trans. A 35, 2903 (2004)

[22] C.R. Clopet, R.F. Cochrane, A.M. Mullis, Acta Mater. 61, 6894 (2013) 